\title{
Brand Image Models of Non-Durable Products: An Exploratory Study
}

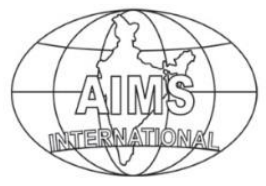

DOI: $10.26573 / 2021.15 .2 .4$

Volume 15, Number 2

May 2021, pp. 119-135

\author{
Nitin Kumar Saxena \\ Jaipuria School of Business \\ (drnitinkrsaxena@gmail.com)
}

Upinder Dhar

Shri Vaishnav Vidyapeeth Vishwavidyalaya

(upinderdhar@gmail.com)

Marketing managers throughout the world have reported continuously brand image measurement as a critical issue. Regardless of substantial empirical research, results on the relationship among constructs related to the brand image are often unpredictable. Many researchers, taking the clue from the discrepancy of results in this area, have suggested that a synthesis across the numerous empirical studies is desirable. Studies focusing on the brand image in the literature have relied on many surrogates like brand awareness, brand loyalty, brand personality, brand character, and so on. However, none of the models so far attempt to capture all the aspects of a brand image from the users' perspective. The present study aimed at identifying the brand image models with special reference to chocolates and soaps. The data was collected from the consumers of chocolates and soaps. A three-tier model has been proposed by the authors to assess the brand image of each product. The study explores dimensions, factors, and attributes leading to brand image building for chocolates and soaps. The present research has implications for practitioners as well as policymakers.

Keywords: Brand Image, Brand Dimensions, Instrument Development, NonDurable Products, Factor Analysis

\section{Introduction}

Arai et al. (2013) believed that brand image is the consumer perception about the brand reflected by a set of brand associations held in consumer's memory. Anselmsson et al. (2014) claimed that brand image is also an outcome of the associations and beliefs that the customer has regarding the brand. In the 1980s, attitude-based image research linked the brand image with the consumer behavior and marketing management (Zinkhan and Hirschheim, 1992). Several empirical studies have confirmed that a favorable image (i.e., brand, store/retail) may lead to loyalty (Kandampully and Suhartanto, 2000), brand equity (Hsiech, 2002 and Faircloth et al., 2001), purchase behavior (Hsieh et al., 2004 and Dolich, 1969) and brand performance (Roth, 1995).

From 1950 through the 1970s, brand image was defined as the sum of a customer's cognitive and affective perceptions along with a product's physical attributes 
(Gardner and Levy, 1955; Newman, 1957; Pohlman and Mudd, 1973). The emphasis was on goods and not on services. Consequently, product image was replaced for most of the definitions of brand image (Pohlman and Mudd, 1973). Few researchers used meanings (Levy and Glick, 1973), symbols (Grubb and Grathwohl, 1967; Pohlman and Mudd, 1973), and associations like attitudes, feelings, and beliefs to define a brand image. During the 1980s, brand image was set, measured, and researched from the perspective of the symbolic meaning of products (Friedmann and Lessig, 1987). Researchers used messages (Swartz, 1983), meanings (Durgee and Stuart, 1987) and associations to depict abstract perceptions of their customers.

Aaker (1996) employed the concept of brand identity, which refers to "a unique set of associations that the brand strategist aspires to create or maintain. "Brand image is in the context of the sender's perspective. Keller (1993) initially defined brand image based on "associative network models of memory." This approach asserted the belief that customers' informational nodes were linked to brands in their memories. Belen et al. (2001) contended that brand image is the perception about a brand as reflected by the cluster of associations that consumers connect to the brand name in memory. Roy and Banerjee (2014) claimed that brand image is the perception of a brand that is formed in the process of decoding brand identity facets.

\section{Conceptual Framework}

Papadimitriou et al. (2016) studied the dimensions of the brand image of an international sports event and revealed five core brand image dimensions: competition, emotional, social, cultural, and organizational. A study was carried out by Burmann et al. (2008) on the influence of industry image on brand image formation. The author identified three factors that influence brand image formation, namely- industry factors, internal brand identity factors, and customers' buying motives coupled with experience (personal factors). Pich and Armannsdottir (2015) have done work on how to operationalize the external brand image of a political brand. The study described how to use political and non-political brands as a source to discover external brand image and compare its consistency with internal brand identity.

A significant advantage of the corporate brand image is a natural brand extension and trust development among the customers. Lin et al. (2013) studied that different brand images have a substantial impact on the assessment of brand extension. A study carried by Chinomona (2016), claimed that brand communication has a strong effect on brand image than on brand trust. However, brand image strongly influences brand trust. Sjodin and Torn (2006) found that corporate communication should be in line with the existing brand image, and any discrepancy between the two may negatively impact brand image and may reduce credibility. The current decade also saw the use of Lexicographic Analysis for measurement of the brand image, which helped indistinct brand image measurement for retail store brands on multiple factors of brand image associations like their variety, wealth, strength, uniqueness, and differentiation (Cortazar and Vela, 2015).

Yang et al.(2011) found that there is a positive transfer effect of celebrity image on brand Image. It can be either way. Sulkunen (2012) has seen that brand image formation happens through familiarity, attitude, and knowledge of the consumer. A 
study on the country of origin, brand image perception, and brand image structure exposed that country of origin has a multi-dimensional influence on the brand image (Koubaa 2008). Bruwerand Johnson (2010) studied that wine brand building hinge on quality and region of production. The study established that consumers used local branding cues, images, and information in their valuation of comparative wine labels. Nearly without exception, the addition of regional news on a wine label amplified consumer assurance in the quality of the product.

Beneke et al. (2014) claimed that brand involvement has a moderating effect on the impact of media richness and interactivity on brand image and brand attitude. The results highlighted that interactivity had a positive impact on brand attitude. Likewise, the brand attitude strongly connected to the brand image. Building a sharp brand image requires to engage with customers on fan pages in regularly answering to their comments and permitting them to upload appropriate content. Online reviews, blogs on brand consumption experiences have more impact than oral communication to build a powerful brand image. Furthermore, reliable online reviews have more influence on hedonic brand image in the context of consumer electronics products in India (Chakraborty and Bhat, 2018).

Saxena and Dhar (2017) in a study observed that looking at the current market scenario where consumers are bombarded with the flood of choices to confuse them about the selection criteria, consumers are expected to look at something other than tangibles associated with the products, and that something is a brand image. When a brand is constituted, it is essential to get the essence first, which gets translated into benefits for the customers. It is the benefits attached to the product or the brand that induces the sense of attachment, which further gets deepened and strong, resulting in brand image formation.

The available literature suggests that there is a difference in understanding the dimensions, factors, and attributes responsible for brand image building in the Indian context. The brand image dimensions need to be further understood to provide any additional insight to marketers in building an effective and sustainable brand image. The three-tier models of brand image evolved through the present study for the brand image dimensions of chocolates, and soaps have been presented to facilitate the assimilation of new knowledge into the existing mass of literature. This study will also assist the practitioners and the academicians, in general, to undertaking the new area of research.

\section{Scale Development}

An exploratory study was carried out with a 'multi-stage randomized' design to understand the perception of users about the image of the products. The purpose of the study was to explore and propose a Brand Image Model for two non-durable products, i.e., chocolates and soaps. These models will help to distinguish their images and to create an understanding of how the brand image dimensions can help people to grasp the intricacies of brand purchase and use in a better manner.

First, the list of image attributes developed based on the review of relevant literature, and then the revised list of image attributes was prepared after churning out of the initial list of image attributes by eliminating the synonyms and similar characteristics. The remaining list of attributes were presented to the 30 Judges 
(academicians and executives having work experience of at least ten years after obtaining the postgraduate education) with the request to identify the ones describing the brand image of the products like chocolates and soaps separately. A list of Image attributes, having $75 \%$ and above acceptance, was prepared. Thus, two separate psychometric tools evolved for the two products on the seven-point bipolar semantic differential scale. The tools were administered separately.

The item-total correlations of the attributes were computed at 0.05 level of significance with the total score followed by the exploratory factor analysis on the data generated by administering the scales to identify the factors for each product. Second-Order Factor Analysis was undertaken to cluster the factors for identifying the dimensions of the brand image for each product.

Through a purposive random sampling method, initial data was collected from a sample of 268 respondents who were the users and consumers of chocolate and soap, out of 268 respondents - 133 for chocolates and 135 for soaps. The data was collected from Delhi-NCR, Bhopal, Indore, Gwalior, Jaipur, Udaipur, Lucknow, Kanpur, and Dehradun. After screening, a final sample of 125 responses was retained for analysis in each product. The reliability of the instruments was calculated by the split-half method corrected for full length by applying the Spearman-Brown Prophecy formula. When an instrument is developed for a particular situation, the reliability index based on the reliability coefficient can be taken as equivalent to the validity of the scale.

For Chocolates

Reliability Index $=\sqrt{ } 0.838$

(For Chocolates $)=0.915$

$\begin{array}{lll}\text { For Soaps } & & \\ \text { Reliability Index } & =\sqrt{ } 0.889 \\ \text { (For Soaps) } & = & 0.942\end{array}$

\section{Results}

The KMO and Bartlett's test was administered to evaluate the applicability of the factor analysis. The KMO value of .884 and .835 was observed for chocolates and soaps, respectively, which indicate the adequacy of sample size for factor analysis. 67 attributes of chocolates converged into 15 factors, and after applying second-order factor analysis on these factors, they were converted into 5 dimensions. Similarly, 73 attributes of soaps converged into 17 factors and, in turn, into five dimensions.

While naming the factors and dimensions, two points were taken into consideration. First, the contribution of each attribute to the factor in terms of the factor load. Secondly, the overall meaning of all the elements combined.

Table 1 Chocolates: Factors and Dimensions

\begin{tabular}{|c|l|c|c|c|}
\hline Factors & Characteristics & Loading & Total Factor & Percentage of \\
\hline \multirow{2}{*}{ Attractive } & Good-Looking & 0.799 & \multirow{2}{*}{4.106} & \multirow{2}{*}{14.42} \\
\cline { 2 - 3 } & Glamorous & 0.712 & & \\
\cline { 2 - 3 } & Charming & 0.681 & & \\
\hline
\end{tabular}




\begin{tabular}{|c|c|c|c|c|}
\hline & Adorable & 0.617 & & \\
\hline & Upper Class & 0.508 & & \\
\hline & Feminine & 0.416 & & \\
\hline & Smooth & 0.373 & & \\
\hline \multirow{6}{*}{ Pleasant } & Cheerful & 0.827 & \multirow{6}{*}{3.621} & \multirow{6}{*}{5.88} \\
\hline & Exciting & 0.727 & & \\
\hline & Friendly & 0.658 & & \\
\hline & Sentimental & 0.538 & & \\
\hline & Humble & 0.474 & & \\
\hline & Sparkling & 0.397 & & \\
\hline \multirow{6}{*}{ Rewarding } & Successful & 0.785 & \multirow{6}{*}{3.172} & \multirow{6}{*}{5.33} \\
\hline & Leader & 0.621 & & \\
\hline & Humorous & 0.525 & & \\
\hline & Fun-Loving & 0.454 & & \\
\hline & Truthful & 0.409 & & \\
\hline & Jolly & 0.378 & & \\
\hline \multirow{5}{*}{ Vigorous } & Energetic & 0.775 & \multirow{5}{*}{2.732} & \multirow{5}{*}{4.27} \\
\hline & Dynamic & 0.604 & & \\
\hline & Outgoing & 0.517 & & \\
\hline & Smart & 0.490 & & \\
\hline & Day-Dreamer & 0.346 & & \\
\hline \multirow{5}{*}{ Decent } & Honest & 0.832 & \multirow{5}{*}{2.678} & \multirow{5}{*}{3.81} \\
\hline & Authentic & 0.729 & & \\
\hline & Decent & 0.642 & & \\
\hline & Real & 0.532 & & \\
\hline & Excitable & 0.346 & & \\
\hline \multirow{4}{*}{ Impressive } & Unique & 0.800 & \multirow{4}{*}{2.525} & \multirow{4}{*}{3.40} \\
\hline & Royal & 0.694 & & \\
\hline & Sensitive & 0.592 & & \\
\hline & Imaginative & 0.440 & & \\
\hline \multirow{4}{*}{ Viable } & Down-to-earth & 0.766 & \multirow{4}{*}{2.407} & \multirow{4}{*}{3.27} \\
\hline & Approachable & 0.681 & & \\
\hline & Enthusiastic & 0.574 & & \\
\hline & Fascinating & 0.386 & & \\
\hline \multirow{4}{*}{ Admired } & Prestigious & 0.771 & \multirow{4}{*}{2.400} & \multirow{4}{*}{3.20} \\
\hline & Elegant & 0.676 & & \\
\hline & Independent & 0.539 & & \\
\hline & Sophisticated & 0.414 & & \\
\hline \multirow{3}{*}{ Credible } & Trustworthy & 0.745 & \multirow{3}{*}{2.383} & \multirow{3}{*}{3.00} \\
\hline & Reliable & 0.625 & & \\
\hline & Loyal & 0.596 & & \\
\hline
\end{tabular}




\begin{tabular}{|c|c|c|c|c|}
\hline & Visionary & 0.487 & & \\
\hline \multirow{4}{*}{ Refreshing } & Cool & 0.719 & \multirow{4}{*}{2.381} & \multirow{4}{*}{2.79} \\
\hline & Young & 0.638 & & \\
\hline & Frank & 0.537 & & \\
\hline & Warm & 0.487 & & \\
\hline \multirow{4}{*}{ Genuine } & Dependable & 0.712 & \multirow{4}{*}{2.332} & \multirow{4}{*}{2.54} \\
\hline & Secure & 0.673 & & \\
\hline & Passionate & 0.527 & & \\
\hline & Bright & 0.411 & & \\
\hline \multirow{4}{*}{ Lovable } & Kind & 0.749 & \multirow{4}{*}{2.296} & \multirow{4}{*}{2.49} \\
\hline & Happy & 0.685 & & \\
\hline & Soft & 0.529 & & \\
\hline & Tender & 0.383 & & \\
\hline \multirow{4}{*}{ Amazing } & Generous & 0.788 & \multirow{4}{*}{2.118} & \multirow{4}{*}{2.45} \\
\hline & Polite & 0.545 & & \\
\hline & Emotional & 0.416 & & \\
\hline & Witty & 0.368 & & \\
\hline \multirow{3}{*}{ Superior } & Perfectionist & 0.784 & \multirow{3}{*}{1.990} & \multirow{3}{*}{2.24} \\
\hline & Appealing & 0.671 & & \\
\hline & Up-to-date & 0.535 & & \\
\hline \multirow{3}{*}{ Convenient } & Responsive & 0.800 & \multirow{3}{*}{1.709} & \multirow{3}{*}{2.19} \\
\hline & Spirited & 0.694 & & \\
\hline & Caring & 0.436 & & \\
\hline
\end{tabular}

\begin{tabular}{|c|c|c|c|c|}
\hline Dimensions & Factors & Loading & Total Factor & Percentage of \\
\hline \multirow{4}{*}{ Worthwhile } & Viable & 0.792 & \multirow{4}{*}{2.454} & \multirow{4}{*}{16.70} \\
\hline & Refreshing & 0.691 & & \\
\hline & Attractive & 0.553 & & \\
\hline & Decent & 0.418 & & \\
\hline \multirow{4}{*}{ Vivid } & Vigorous & 0.806 & \multirow{4}{*}{2.217} & \multirow{4}{*}{13.80} \\
\hline & Pleasant & 0.582 & & \\
\hline & Convenient & 0.417 & & \\
\hline & Rewarding & 0.407 & & \\
\hline \multirow{3}{*}{ Authentic } & Credible & 0.844 & \multirow{3}{*}{1.885} & \multirow{3}{*}{12.60} \\
\hline & Superior & 0.573 & & \\
\hline & Impressive & 0.437 & & \\
\hline \multirow[t]{2}{*}{ Legitimate } & Genuine & 0.838 & \multirow{2}{*}{1.440} & \multirow[t]{2}{*}{10.50} \\
\hline & Admired & 0.602 & & \\
\hline \multirow[t]{2}{*}{ Opulent } & Amazing & 0.870 & \multirow[t]{2}{*}{1.401} & \multirow[t]{2}{*}{9.70} \\
\hline & Lovable & 0.530 & & \\
\hline
\end{tabular}


Table 2 Soaps: Factors and Dimensions

\begin{tabular}{|c|c|c|c|c|}
\hline Factors & Characteristics & Loading & Total Factor & Percentage of \\
\hline \multirow{7}{*}{ Safe } & Reliable & 0.822 & \multirow{7}{*}{4.540} & \multirow{7}{*}{18.20} \\
\hline & Honest & 0.814 & & \\
\hline & Loyal & 0.660 & & \\
\hline & Truthful & 0.654 & & \\
\hline & Dependable & 0.584 & & \\
\hline & Authentic & 0.522 & & \\
\hline & Sensitive & 0.483 & & \\
\hline \multirow{6}{*}{ Alluring } & Good Looking & 0.894 & \multirow{6}{*}{3.628} & \multirow{6}{*}{5.65} \\
\hline & Glamorous & 0.740 & & \\
\hline & Elegant & 0.635 & & \\
\hline & Upper Class & 0.512 & & \\
\hline & Royal & 0.457 & & \\
\hline & Smooth & 0.391 & & \\
\hline \multirow{5}{*}{ Persuasive } & Energetic & 0.763 & \multirow{5}{*}{2.992} & \multirow{5}{*}{4.42} \\
\hline & Outgoing & 0.648 & & \\
\hline & Outdoorsy & 0.591 & & \\
\hline & Smart & 0.535 & & \\
\hline & Dynamic & 0.462 & & \\
\hline \multirow{5}{*}{ Charming } & Kind & 0.737 & \multirow{5}{*}{2.916} & \multirow{5}{*}{4.06} \\
\hline & Polite & 0.668 & & \\
\hline & Caring & 0.532 & & \\
\hline & Soft & 0.503 & & \\
\hline & Tender & 0.484 & & \\
\hline \multirow{5}{*}{ Commanding } & Leader & 0.731 & \multirow{5}{*}{2.752} & \multirow{5}{*}{3.87} \\
\hline & Successful & 0.644 & & \\
\hline & Responsive & 0.542 & & \\
\hline & Glorious & 0.409 & & \\
\hline & Splendid & 0.378 & & \\
\hline \multirow{5}{*}{ Effervescent } & Cheerful & 0.742 & \multirow{5}{*}{2.701} & \multirow{5}{*}{3.77} \\
\hline & Humble & 0.624 & & \\
\hline & Passionate & 0.513 & & \\
\hline & Humorous & 0.427 & & \\
\hline & Family Oriented & 0.395 & & \\
\hline \multirow{4}{*}{ Impressive } & Masculine & 0.869 & \multirow{4}{*}{2.629} & \multirow{4}{*}{3.37} \\
\hline & Rigid & 0.739 & & \\
\hline & Hardworking & 0.641 & & \\
\hline & Persevering & 0.416 & & \\
\hline \multirow{4}{*}{ Vivacious } & Spirited & 0.826 & \multirow{4}{*}{2.545} & \multirow{4}{*}{3.17} \\
\hline & Cool & 0.716 & & \\
\hline & Real & 0.568 & & \\
\hline & Young & 0.436 & & \\
\hline
\end{tabular}




\begin{tabular}{|c|c|c|c|c|}
\hline \multirow{5}{*}{ Superior } & Dominant & 0.698 & \multirow{5}{*}{2.001} & \multirow{5}{*}{3.11} \\
\hline & Sophisticated & 0.508 & & \\
\hline & Decent & 0.443 & & \\
\hline & Mild & 0.389 & & \\
\hline & Fascinating & 0.352 & & \\
\hline \multirow{4}{*}{ Vivid } & Bright & 0.710 & \multirow{4}{*}{2.350} & \multirow{4}{*}{2.90} \\
\hline & Sparkling & 0.632 & & \\
\hline & Shinny & 0.548 & & \\
\hline & Enthusiastic & 0.460 & & \\
\hline \multirow{4}{*}{ Enjoyable } & Jolly & 0.783 & \multirow{4}{*}{2.345} & \multirow{4}{*}{2.85} \\
\hline & Happy & 0.650 & & \\
\hline & Fun-Loving & 0.529 & & \\
\hline & Frank & 0.383 & & \\
\hline \multirow{4}{*}{ Fulfilling } & Perfectionist & 0.780 & \multirow{4}{*}{2.169} & \multirow{4}{*}{2.65} \\
\hline & Thoughtful & 0.532 & & \\
\hline & Unique & 0.471 & & \\
\hline & Secure & 0.386 & & \\
\hline \multirow{3}{*}{ Legitimate } & Down-to-earth & 0.825 & \multirow{3}{*}{1.914} & \multirow{3}{*}{2.58} \\
\hline & Original & 0.670 & & \\
\hline & Contemporary & 0.419 & & \\
\hline \multirow{3}{*}{ Satisfying } & Generous & 0.767 & \multirow{3}{*}{1.665} & \multirow{3}{*}{2.49} \\
\hline & Confident & 0.542 & & \\
\hline & Persistent & 0.357 & & \\
\hline \multirow{3}{*}{ Gorgeous } & Day-Dreamer & 0.675 & \multirow{3}{*}{1.618} & \multirow{3}{*}{2.26} \\
\hline & Emotional & 0.589 & & \\
\hline & Exciting & 0.354 & & \\
\hline \multirow{3}{*}{ Avid } & Competitive & 0.819 & \multirow{3}{*}{1.653} & \multirow{3}{*}{2.20} \\
\hline & Independent & 0.447 & & \\
\hline & Visionary & 0.387 & & \\
\hline \multirow{3}{*}{ Assuring } & Committed & 0.584 & \multirow{3}{*}{1.417} & \multirow{3}{*}{2.18} \\
\hline & Friendly & 0.466 & & \\
\hline & Charming & 0.368 & & \\
\hline
\end{tabular}

\begin{tabular}{|c|c|c|c|c|}
\hline Dimensions & Factors & Loading & Total Factor & Percentage of \\
\hline \multirow{5}{*}{ Credible } & Persuasive & 0.833 & \multirow{5}{*}{3.145} & \multirow{5}{*}{16.30} \\
\hline & Alluring & 0.713 & & \\
\hline & Commanding & 0.598 & & \\
\hline & Effervescent & 0.518 & & \\
\hline & Avid & 0.483 & & \\
\hline \multirow{4}{*}{ Pure } & Legitimate & 0.880 & \multirow{4}{*}{2.515} & \multirow{4}{*}{14.20} \\
\hline & Vivacious & 0.698 & & \\
\hline & Superior & 0.529 & & \\
\hline & Fulfilling & 0.406 & & \\
\hline
\end{tabular}




\begin{tabular}{|l|l|l|l|c|}
\multirow{3}{*}{ Delightful } & Satisfying & 0.870 & \multirow{2}{*}{1.806} & 13.80 \\
\cline { 2 - 3 } & Enjoyable & 0.610 & & \\
\cline { 2 - 3 } & Gorgeous & 0.325 & & \multirow{2}{*}{1.755} \\
\hline \multirow{3}{*}{ Lovable } & Charming & 0.819 & 12.20 \\
\cline { 2 - 3 } & Vivid & 0.617 & & \\
\cline { 2 - 3 } & Impressive & 0.317 & & 10.90 \\
\hline \multirow{2}{*}{ Harmless } & Safe & 0.797 & 1.125 & \\
\cline { 2 - 3 } & Assuring & 0.328 & & \\
\hline
\end{tabular}

\section{Brand Image Models for Chocolates and Soaps}

Based on the above analysis, three-tier models to assess the brand image of chocolates and soaps were proposed, respectively. The model captures the brand image at 3 different levels of granularity, namely, attributes, factors, and dimensions. The three-tier factorial constitution of the Brand Image of Chocolates has Worthwhile, Vivid, Authentic, Legitimate, and Opulent dimensions at the top of the pyramid. These dimensions have a composition of factors like Attractive, Impressive, Refreshing, and Lovable, to name some of them. Further, the bottom of the pyramid has attributes like Adorable, Charming, Happy, Real, Sparkling, Tender, and others, as shown in Figure 1.

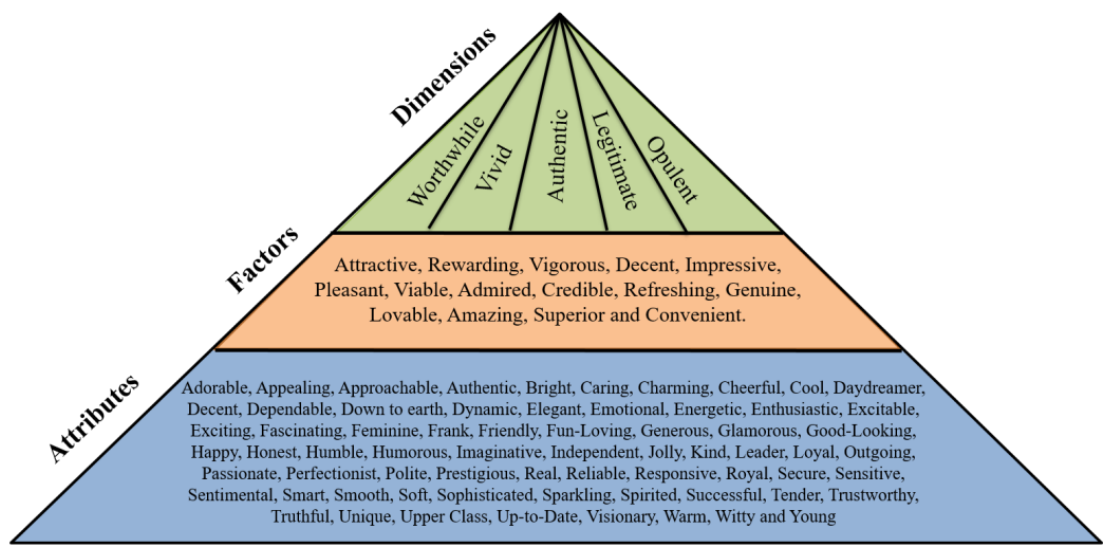

Figure 1 Showing Three Tier Brand Image Model of Chocolates

The three-tier factorial constitution of the Brand Image of Soaps has Credible, Pure, Delightful, Lovable, and Harmless dimensions at the apex of the pyramid. These dimensions have a composition of the factors like Safe, Effervescent, Enjoyable, Gorgeous, and Vivid, to name a few of them. Further, the base of the pyramid has attributes like Bright, Caring, Daydreamer, Glamorous, Secure, Young, and others, as shown in Figure 2 


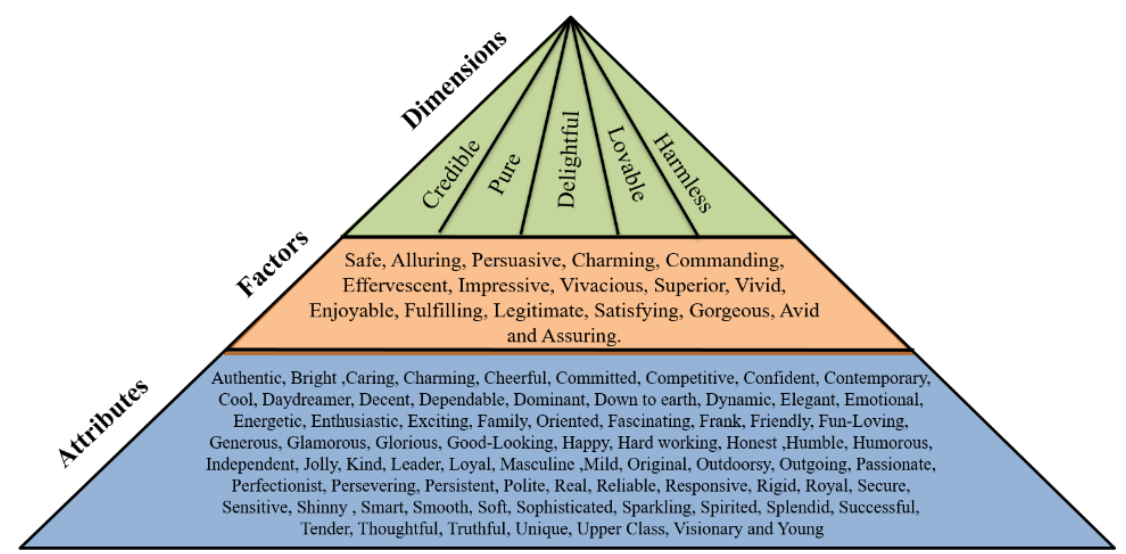

Figure 2 Showing Three Tier Brand Image Model of Soaps

\section{Comparison of Common Factors and Dimensions}

In the study, two factors emerged as common among brands of chocolates and soaps, resulting in the formation of 2 null hypotheses. To test these hypotheses, " $z$ " tests were conducted.

$\mathrm{H}_{0.1} \quad$ There is no significant difference in the perception of customers on the Superior factor of the brand image of chocolates and soaps.

$\mathrm{H}_{0.2} \quad$ There is no significant difference in the perception of customers on the Impressive factor of the brand image of chocolates and soaps.

\begin{tabular}{|c|c|c|c|c|c|c|c|}
\hline \multirow{2}{*}{ Factors } & \multicolumn{2}{|c|}{ Chocolates } & \multicolumn{2}{|c|}{ Soaps } & \multirow{2}{*}{$\begin{array}{c}\mathbf{z} \\
\text { Value }\end{array}$} & \multirow{2}{*}{ Hypothesis } & \multirow{2}{*}{ Interpretation } \\
\hline & Mean & $\begin{array}{l}\text { Std. } \\
\text { Dev. }\end{array}$ & Mean & $\begin{array}{l}\text { Std. } \\
\text { Dev. }\end{array}$ & & & \\
\hline Superior & $\begin{array}{c}18.32 \\
0\end{array}$ & 1.619 & $\begin{array}{c}30.19 \\
2\end{array}$ & 2.755 & 41.530 & Rejected & $\begin{array}{l}\text { Customers of } \\
\text { soaps give } \\
\text { higher } \\
\text { weightage to the } \\
\text { Superior factor } \\
\text { as compared to } \\
\text { the customers of } \\
\text { chocolates }\end{array}$ \\
\hline $\begin{array}{l}\text { Impressi } \\
\text { ve }\end{array}$ & $\begin{array}{c}24.24 \\
8\end{array}$ & 2.601 & $\begin{array}{c}20.72 \\
0\end{array}$ & 3.633 & 8.826 & Rejected & $\begin{array}{l}\text { Customers of } \\
\text { chocolates give } \\
\text { higher } \\
\text { weightage to the } \\
\text { Impressive } \\
\text { factor } \\
\text { compared to the } \\
\text { customers of } \\
\text { soaps }\end{array}$ \\
\hline
\end{tabular}




\subsection{Attractive, Rewarding and Vigorous}

\section{Discussion}

Brand induces the feeling of being attractive in terms of look and feel. For chocolate brands, aroma, taste, and seductive attitude lead to the impression of being attractive to the users. The emergence of rewarding as a factor of brand image can be attributed to the brands which have consistently over-delivered in terms of value to the users may be perceived as being valuable towards the audience. Also, if this value reaches the users at a minimum possible cost, the perception will be reinforced, and users may view the brand as being unselfish in its intent, thus construed as being rewarding. The emergence of vigorous as a factor of brand image is the result of the users' perception of the brands being characterized by active strength in their appearance and performance. This factor resembles the energetic factor of the brand personality of soaps (Mishra, 2002). Decent as a factor of brand image is the reflection of customers' perception of the brand being honest, authentic, and decent in its construct and dealings. Users view these brands as real and excitable. Those brands, which can create an impression of excellence and being a class apart from others, were perceived as impressive by the users.

Friendly attitude, feeling of happiness in the usage of the brand, excitement in discussing the brand, emotional attachment, and politeness of the brand lead to the feeling of the brand being pleasant. The emergence of viable as a factor of brand image can be attributed to the practical approach towards the customers. A viable factor is correlated to the affordability factor of the brand image of stores (Kremer and Viot, 2012). Admired as a factor of the brand image reflects the brands' ability to create the value proposition as honorable and distinguished from their competitors. The emergence of credible as a factor of brand image can be attributed to the brands' consistency in their promise and performance. This factor is in line with the trustworthy factor of the brand character of insurance (Johari, 2005). Chocolate brands are perceived as refreshing as they rejoice the customers' mood by their fresh taste, aroma, and energizing effect. Consuming chocolate gives a feeling of being young and cool to the users. This factor resembles the energetic factor of the brand personality of soaps (Mishra, 2002). Genuine, as a factor of the brand image, reflects the fact that brands are sensitive to the needs of the users and understand the importance of being ethical in their dealings to create a positive impact on the users. The Genuine factor is like a good deal factor of the brand image of stores (Kremer and Viot, 2012).

The Lovable factor of the brand image reflects the brands' capability of generating intense feeling amongst their users. This factor is in line with the gentle element of the brand character of insurance (Johari, 2005). This factor seems to be comparable with the Eysenck's dimension of an emotionally stable introvert. The emergence of amazing as a factor of the brand image signifies the brands' capability to differentiate itself due to the unique attributes like generousness, emotional bonding, politeness, and witty nature. This factor is supported by the chocolate affinity factor that is resulting in the purchase of chocolate (Patwardhan et al., 2010). Superior as a factor of brand image is the outcome of the brands' aptitude to comprehend the needs of the customers. These brands are perceived as exciting, engaging, and quick in understanding their explicit and inexplicit needs. The superior factor is like the 
mellowed factor of brand personality of soaps (Mishra, 2002).The emergence of convenience as a factor of the brand image signifies that the brands are readily available in all price bands and variants and keep the customers' interest in mind. This factor appears to be closer to the convenience and sustainability factor of the brand image of stores (Kremer and Viot, 2012).

\subsection{Safe, Alluring and Persuasive}

Safe as a factor of the brand image signifies the brands' success in making the users believe that they are reliable, truthful, and trustworthy. These brands deliver their promises with honesty and gain customer loyalty. Users see these brands as dependable, authentic, and sensitive towards them and their needs. The emergence of alluring as a factor of the brand image of soaps is because of the charm and glamour the brand creates through different components of the architecture. Communication, packaging, colour, and fragrance all combine to create a soothing aura in the consumers' minds. This factor resembles the enchanting factor of the brand personality of soaps (Mishra, 2002). Persuasive as a factor of brand image is the result of the convincing and compelling attitude that a brand creates in the customers' minds through different elements of the architecture. The persuasive factor can be compared to attractive packaging and scheme factors resulting in the purchase of soap (Patwardhan et al., 2010).

Charming as a factor of the brand image signifies the warmth and responsiveness of the brand towards the users' needs and wants through their form and performance. The Charming factor can be compared to the benevolent factor of the brand character of insurance (Johari, 2005) and the brand personality of soaps (Mishra, 2002). Commanding as a factor of the brand image of soaps reflects their leadership and success in the users' minds. These brands also gain this status by being responsive in their nature and glorious in their attitude. The emergence of effervescent as a factor of brand image can be attributed to the brands' capability in generating cheerful, impressive, and humorous feelings amongst their users. The effervescent factor of the brand image also resembles the Cattell's personality description of outgoing. Brands that can create an impression of their masculine and rigid attitude, and being a class apart from other brands, are perceived as impressive by the users. Such perceptions can be seen as an outcome of hard work and perseverance.

The emergence of vivacious as a factor of the brand image reflects the appearance and communication elements of the brand being fun and frolic. These brands tickle the heart of the users and are viewed as vivacious. The emergence of superior as a factor of brand image is perceived as the brands' ability to understand the requirement of customers. Customers tend to depend more on those brands which they perceive as appealing, focused, and intelligent in understanding their overt and latent needs. Brands having the radiance of beauty, brightness, sparkling, and shiny attitude in their design is reinforced through their performance, and other interactions amongst the users are perceived as vivid. These brands are enthusiastic about their users. The brands which choose to make humor as an emotional content in communication and appearance are perceived as enjoyable. Such stature is achieved through tangible and intangible elements of the brand, such as packaging and communication. 
Soap brands are seen as fulfilling due to elements like fragrance, ingredients, and all skin type variants. The emergence of legitimate as a factor of the brand image signifies the brands' ability to create the feeling of attachment with a person through continuous use. Satisfying as a factor of the brand image means that the brands have consistently and generously over-delivered in terms of value to the users. The emergence of gorgeous as a factor of brand image is attributed to the fact that soaps require a high degree of trust to be vested in them while users make their selection for keeping them to look beautiful. Avid brands show consistent determination and firmness in their efforts to serve their customers. Their competitive, independent, and visionary elements lead to the perception of the brand being avid. Assuring, as a factor of the brand image, reflects that the brands are committed towards customers' interests. Their friendly approach towards the customers is another reason for this perception.

\subsection{Worthwhile and Credible}

The emergence of worthwhile as a dimension of brand image signals the brand being modest in its claims and generous in performance and value addition to the users. By consistently doing so, the brands have shown the potential of earning the users' respect because they succeeded in creating an impression of an image under promises and over-delivers. This dimension is in line with the utilitarian (Hseih, 2002) and self-expressive dimensions of brand image (Aaker, 2009). The worthwhile aspect of chocolate brands is also supported by the worth dimension of the brand image of mobile handsets comprised of value for price and effective attributes (Bhagwat, 2016). Those brands which can generate a powerful and clear image in the consumers' minds are perceived as vivid. The mere presence or thought of such brands create a vibrant feeling and positive emotions in the users, and they feel pleasant and rewarded for using these brands. This dimension is in line with the image of the product (Beil, 1992) and self-expressive dimensions (Aaker, 2009).

Brands that are capable of satisfying the needs and offering better value to customers successfully are perceived as satisfying. Aroma, taste, hygiene, and quality are few elements that build trust among the users and they perceive the brands as proficient and exclusive. The satisfying dimension of the brand image of chocolates can be viewed in the light of the sensory (Roth, 1995; Hseih, 2002) and selfexpressive dimensions (Aaker, 2009). The satisfying dimension of the brand image also resembles the competence dimension of corporate brand image (Davies et al., 2003) and brand image of financial services (Moin, 2016). This dimension can also be compared to the efficiency dimension of the brand image of non-profit organizations (Michel and Rieunier, 2012).Legitimate as a dimension of the brand image of chocolates reflects that customers view brands as genuine in their quality content. The brands are also viewed as dependable as they cater to the customers' interests. Customers believe that the legitimate dimension of brand image is an indicator of not compromising on the quality of ingredients used. This dimension is in line with the corporate image (Beil, 1992) and functional image dimensions (Hariri and Vazifehdust, 2011). The legitimate dimension of brand image can also be compared with the dependable dimension of the brand personality seen as an outcome of the brands' quality content and their honesty in serving their customers (Mishra, 2002). 
Brands that can amaze the customers and create an impression of joy, love, and charm are perceived as opulent. Such perception can be seen as an outcome of the brands' appearance, their happy go luck attributes, and also the comfort and elegance in their form. Opulent can be compared to price dimension of brand image of store in the context of good deals and value for money (Kremer and Viot, 2012). This dimension is in line with affective image (Hariri and Vazifehdust, 2011) and sensory dimensions (Roth, 1995 and Hseih, 2002). Opulent dimension is like impressive dimension of the brand image of a mobile handset comprised of prestigious, cool, good looking, secure and classy (Bhagwat, 2016). The emergence of credible as a dimension of the brand image of soaps can be attributed to their persuasive, alluring, commanding, effervescent, and vivid characteristics. The brands are strong in their communication with their customers on the credibility front. This also helps customers to make a faster and easier decision for purchase. The emergence of pure as a dimension of the brand image of soaps can be attributed to their legitimate, vivacious, superior ad fulfilling nature. The brands are characterized by relative perfection in their constitution. In the case of soap brands, health is the primary concern, and brands perceived as pure are seen as constituted of un-harmful elements. The pure dimension of soap brands is like the reputation dimension of corporate brand image (Wei, 2002), commitment dimension of online-offline store image (Bravo et al., 2011), and perceived quality dimension in influencing purchase intentions of banking services (Srivastava and Dey, 2016).

Those brands which can generate satisfying and enjoyable feelings through their association with users were perceived as delightful. Such perception can be seen as an outcome of the brands' persistent efforts in delighting the customers by catering to their smallest needs. Lovable brands make all efforts in the form of advertising campaigns, loyalty programs, packaging, punch lines, and all brand exercises in communicating the benevolence, charming, vivid, and impressive image of the brand. Brands are perceived as harmless when they keep the benefit of the customer in mind and present themselves as safe, friendly, and honest. This is explicitly applicable to soap brands as they have to give an assurance to the customers that soap will be gentle and mild on their skin. Harmless dimension is supported by the emotional value dimension in influencing purchase intentions of banking services (Srivastava and Dey, 2016) and commitment dimension of online-offline store image (Bravo et al. 2011).The harmless dimension of brand image is viewed in the light of caring dimension of brand image of mobile services comprised of supportive, trustworthy, secure, friendly, responsible, helping, responsive, fast, value for price, and reliable attributes (Bhagwat, 2016).

\section{Implications and Scope for Future Research}

The brand image psychometric instruments developed in this study can be useful for further exploration concerning developmental issues and processes of brand management. Research on the brand image can be done by comparing the brand image of all brands in a particular product category. This exercise can be replicated for several product categories in the FMGC industry, which will fuel the development of a framework of brand image. The policymakers can use the results of the present study in establishing product benchmark on these factors and dimensions 
in the Indian market and may help the customers in getting a decent, honest, and valuable product. At the same time, these dimensions may be useful for judicial authorities or consumer forums in judging the legal cases related to the functional performance of chocolates and soaps.

The present study on the brand image can further be explained in the context of various demographic variables like age, gender, education, and income. Marital status like unmarried and married users, and divorcees or sole survivors may be taken as a variable for assessing the brand image of a product or service. There area probability that customer perception changes regarding the brand image due to the difference in the economic scenario (Saxena and Dhar, 2017). A study can be conducted to compare the perception of customers residing in various metropolitan and other major cities in India. The present study can be expanded to the crosscultural domains to explore the influences of the cultural dissimilarities on brand image construct and secondly, to investigate whether brand image dimensions are consistent across cultures or not?

\section{Conclusions}

The brands or products are bought to satisfy a particular set of needs, so it becomes essential to understand how an individual is relating his need fulfillment with the brand. Especially in the customer-driven economy while choosing a brand, customers prefer brands that are ethical in their dealings and comply with the social norms. Thus, in this light, the emergence of a multilevel three-tier model of the brand image can be seen as an outcome of the need fulfillment process. Bem and Funder (1978) and Snyder et al. (1986), in their respective studies, had confirmed that inanimate objects such as brands could be associated with a set of human characteristics.

\section{References}

1. Aaker, D. A. (1996). Measuring brand equity across products and markets. California Management Review, 38(3), 102-120.

2. Anselmsson, J., Bondesson, N. V., \& Johansson, U. (2014). Brand image and customers' willingness to pay a price premium for food brands. Journal of Product \& Brand Management, 23(2), 3-37.

3. Arai, A., Ko, Y. J., \& Kaplanidou, K. (2013). Athlete brand image: scale development and model test. European Sport Management Quarterly, 13(4), 383-403.

4. Belén del Río, A., Vazquez, R., \& Iglesias, V. (2001). The effects of brand associations on consumer response. Journal of Consumer Marketing, 18(5), 410425.

5. Beneke, J., Blampied, S., Miszczak, S., \& Parker, P. (2014). Social networking the brand - An exploration of the drivers of brand image in the South African beer market. Journal of Food Products Marketing, 20 (4), 362-389.

6. Bruwer, J., \& Johnson, R. (2010). Place-based marketing and regional branding strategy prespectives in the california wine industry. Journal of Consumer Marketing, 27(1), 5-16. 
7. Burmann, C., Schaefer, K., \& Maloney, P. (2008). Industry image: Its impact on the brand image of potential employees. Journal of Brand Management, 15(3), 157-176.

8. Chakraborty, U., \& Bhat, S. (2018). Management Research Review: MRN; Patrington 41(1), 148-164.

9. Chinomona, R. (2016). Brand communication, brand image and brand trust as antecedents of brand loyalty in Gauteng Province of South Africa. African Journal of Economic and Management Studies, 7(1), 124-139.

10. Davies, G., Chun. R., Da Silva, R. V, \& Roper, S. (2003). Corporate character scale to assess employee and customer views of organisation reputation. Corporate Reputation Review, 7 (2), 125-146.

11. Durgee, J. F., \& Stuart, R. W. (1987). Advertising symbols and brand names that best represent key product meanings. Journal of Consumer Marketing, 4(3), 1524.

12. Faircloth, J. B., Capella, L. M., \& Alford, B. L. (2001). The effect of brand attitude and brand image on brand equity. Journal of Marketing Theory and Practice, 9(3), 61-75.

13. Friedmann, R., \& Lessig, V. P. (1987). Psychological meaning of products and product positioning. Journal of Product Innovation Management, 4(4), 265-273.

14. Gardner, B. G., \& Levy, S. J. (1955). The product and the brand. Harvard Business Review, March-April, 33-39.

15. Grubb, E. L., \& Grathwohl, H. L. (1967). Consumer self-concept, symbolism and market behavior: A theoretical approach. The Journal of Marketing, 31(4), 22-27.

16. Hariri, M., \& Vazifehdust, H. (2011). How does brand extension affect brand image? International Conference on Business and Economics Research, 1, 104109.

17. Hsieh, M.H. (2002), "Identifying brand image dimensionality and measuring the degree of brand globalization: a cross-national study", Journal of International Marketing, Vol. 10 No. 2, pp. 46-67

18. Johari, Smriti (2005). Dimensions of Brand Character: An Exploratory Study. Unpublished Ph. D Thesis. Indore: DAVV.

19. Kandampully, J., \& Suhartanto, D. (2000). Customer loyalty in the hotel industry: the role of customer satisfaction and image. International Journal of Contemporary Hospitality Management, 12(6), 346-351.

20. Keller, K. L. (1993). Conceptualizing, measuring, and managing customer-based brand equity. Journal of marketing, 57(1), 1-22.

21. Koubaa, Y. (2008). Country of origin, brand image perception, and brand image structure. Asia Pacific Journal of Marketing and Logistics, 20 (2), 139-155.

22. Kremer, F., \& Viot, C. (2012). How store brands build retailer brand image. International Journal of Retail \& Distribution Management, 40 (7), 528-543

23. Levy, J. Y., \& Glick. O. (1973). "Imagery and Symbolism". Marketing Manager's Handbook.

24. Lin, Y. C., Lee, Y. C., \& Fu, Z. W. (2013). The influence of the brand image and information involvement on the evaluation of brand extension - The case of Taiwan. Journal of Statistics and Management Systems, 16 (4/5), 309-317. 
25. Michel, G., \& Rieunier, S. (2012). Nonprofit brand image and typicality influences on charitable giving. Journal of Business Research, 65 (5), 701-707.

26. Mishra, Prashant (2002). Dimensions of Brand Personality: An Exploratory Study. Unpublished Ph. D Thesis. Indore: DAVV.

27. Moin, S. M. A. (2016). Binding Through Branding: An Investigation into The Impact of Brand Experience and Brand Image on Consumers' Perception of Trust in The Context of The Uk Financial Services Sector. PhD Thesis. Nottingham: University of Nottingham

28. Newman, J. W. (1957). New insight, new progress, for marketing. Harvard Business Review, 35(6), 95-102.

29. Ortegón Cortazar, L., \& Royo Vela, M. (2015). Brand image and lexicographic analysis: An application to shopping malls. Cuadernos de Gestión, 15 (2), 143 162

30. Papadimitriou, D., Apostolopoulou, A., \& Kaplanidou, K. (2016, January). Participant-based brand image perceptions of international sport events: The case of the Universiade. In Journal of convention \& event tourism (Vol. 17, No. 1, pp. 1-20). Routledge.

31. Patwardhan, M., Flora, P., \& Gupta, A. (2010). Identification of secondary factors that influence consumer's buying behavior for soaps and chocolates. IUP journal of marketing management, 9(1/2), 55.

32. Pich, C., \& Armannsdottir, G. (2018). Political brand image: an investigation into the operationalisation of the external orientation of David Cameron's Conservative brand. Journal of Marketing Communications, 24(1), 35-52.

33. Pohlman, A., \& Mudd, S. (1973). Market image as a function of group and product type: A quantitative approach. Journal of Applied Psychology, 57(2), 167-71.

34. Roth, M. S. (1995). Effects of global market conditions on brand image customization and brand performance. Journal of Advertising, 24 (4), 55-75.

35. Roy, D., \& Banerjee, S. (2014). Identification and measurement of brand identity: A quantitative approach. Journal of Product \& Brand Management, 23(3), 6-36.

36. Saxena, N. K., \& Dhar, U. (2017). Brand image: A seasoned review. Asian J. Management, 8 (1), 103-106.

37. Sjodin H., \& Torn F. (2006). "When communication challenges brand associations: a framework for understanding consumer response to brand image congruity" Journal of Consumer Behaviour. Vol. 5, p. 32-42.

38. Sulkunen, S. (2012). A Study of Brand Image. Thesis. JAMK University of Applied Sciences.

39. Swartz, T. A. (1983). Brand symbols and message differentiation. Journal of Advertising Research, 23 (5), 59-64.

40. Yang, D. J., Lo, J. Y., \& Lin, W. C. (2011). The effect of social marketing communication on safe driving. Psychological Reports, 109 (3), 739-754.

41. Zinkhan, G. M., \& Hirschheim, R. (1992). Truth in marketing theory and research: an alternative perspective. The Journal of Marketing, 56 (2), 80-88. 


\section{About Our Authors}

Nitin Kumar Saxena is an Associate Professor in the Marketing area. He holds a Ph.D. in Marketing, and has secured All India Second Rank "Gold Medal" in Marketing Certification course from IIT Kanpur. He has also done certification courses on 'Data Science Using R and Python' and 'Multivariate Data Analysis' and from IIT Roorkee. He has over 14 years of experience in marketing, retail operations, and marketing research in companies like HCL, Idea Cellular, Vodafone, and Spice Retail. He has published two edited books, 30 research papers in National and International Journals of repute. He is the author of www.learnistan.com, a learning resource platform for students.

Upinder Dhar is Vice Chancellor of Shri Vaishnav Vidyapeeth Vishwavidyalaya (Indore). Earlier, he was Group Additional Vice Chancellor and Pro-Vice Chancellor - Academics, Amity University Uttar Pradesh (Noida); First Vice Chancellor of JK Lakshmipat University (Jaipur); He has conducted more than 600 management and faculty development programs for the executives of major business houses and faculty members of academic institutions respectively. He has also been Guest Faculty at IIM Calcutta, IIM Indore, IIM Trichy and IIT Roorkee. Besides undertaking consultancy assignments, he has authored/co-authored more than 640 publications. Thirty-Four (34) scholars have been awarded Ph.D. degree under his supervision by various universities. 